\title{
Stratigraphy of the Lower Pierre Shale (Campanian): Implications for the Tectonic and Eustatic Controls on Facies Distributions
}

\author{
Janet Bertog \\ Department of Physics and Geology, SC 204, Nunn Dr, Northern Kentucky University, Highland Heights, KY 41099, USA \\ Correspondence should be addressed to Janet Bertog, bertogj@nku.edu \\ Received 1 September 2010; Accepted 17 November 2010 \\ Academic Editor: Lisa Tauxe \\ Copyright ( $\odot 2010$ Janet Bertog. This is an open access article distributed under the Creative Commons Attribution License, which \\ permits unrestricted use, distribution, and reproduction in any medium, provided the original work is properly cited. \\ The lower Pierre Shale represents a time of significant changes in the Cretaceous Western Interior Seaway, resulting from complex \\ interactions of tectonism and eustatic sea level changes. The recognition and redefinition of the units of the lower Pierre Shale \\ has facilitated understanding of the dynamics of the basin. The Burning Brule Member of the Sharon Springs Formation is \\ restricted to the northern part of the basin and represents tectonically influenced sequences. These sequences are a response \\ to rapid subsidence of the axial basin and the Williston Basin corresponding to tectonic activity along the Absoroka Thrust in \\ Wyoming. Unconformities associated with the Burning Brule Member record a migrating peripheral bulge in the Black Hills \\ region corresponding to a single tectonic pulse on the Absoroka Thrust. Migration of deposition and unconformities supports an \\ elastic model for the formation and migration of the peripheral bulge and its interaction with the Williston Basin.
}

\section{Introduction}

Timing of thrust activity in tectonically active thrust belts, such as the Cretaceous Sevier Orogenic belt in the western United States, is generally estimated by the recognition of synorogenic clastic sedimentation responding to the thrust activity (see, e.g., [1-4]). Dependence on proximal synorogenic sedimentation can be complicated by two factors. (1) Initial thrusting events may not break the surface and uplift may remain below sea level. As a result no coarse clastic deposition will occur [5]. (2) Proximal sediments are often deformed by later thrust activity [3]. Careful examination of distal sediments can reveal a record of tectonic activity that is not complicated by the issues that affect proximal settings, providing an independent method of evaluating tectonic activity.

The Pierre Shale was deposited in a retroarc foreland basin resulting from subduction of the Farallon Plate under the North American Plate (Figure 1). The lower Pierre Shale (Campanian, Cretaceous) represents an interval of significant changes in the Cretaceous Western Interior Seaway, corresponding to the Claggett Cycle of Kauffman [6] and dated at $81-75 \mathrm{Ma}$ [7]. The lower Pierre Shale indicates a shift from carbonate environments of the Niobrara Formation to clastic environments of the Pierre Shale (Figure 2). The interaction of tectonic events in the Sevier Orogeny and eustatic sea level change resulted in changes in sedimentation and ecology that ultimately resulted in the demise and turnover of several groups of animals [8]. The complex nature of this interval is masked by the recognition of a single stratigraphic unit of the lower Pierre Shale, which has been extended from Kansas to South Dakota, with a duration of approximately 5 million years. This interval includes the widespread Sharon Springs Formation [9]. This correlation over such a large area appears to suggest widespread stability of a single facies. However, detailed stratigraphic analysis of the lower Pierre Shale Group throughout the basin indicates a much more complex distribution of facies. The recognition of these facies changes was reported in Martin et al. [9] and Bertog et al. [10], where the Sharon Springs Formation was divided into three members in central South Dakota and these correlations were expanded to the Black Hills, Kansas and North Dakota (Figure 4). An evaluation of the distribution of these members provides the detail necessary for an interpretation of tectonic patterns in the basin. 


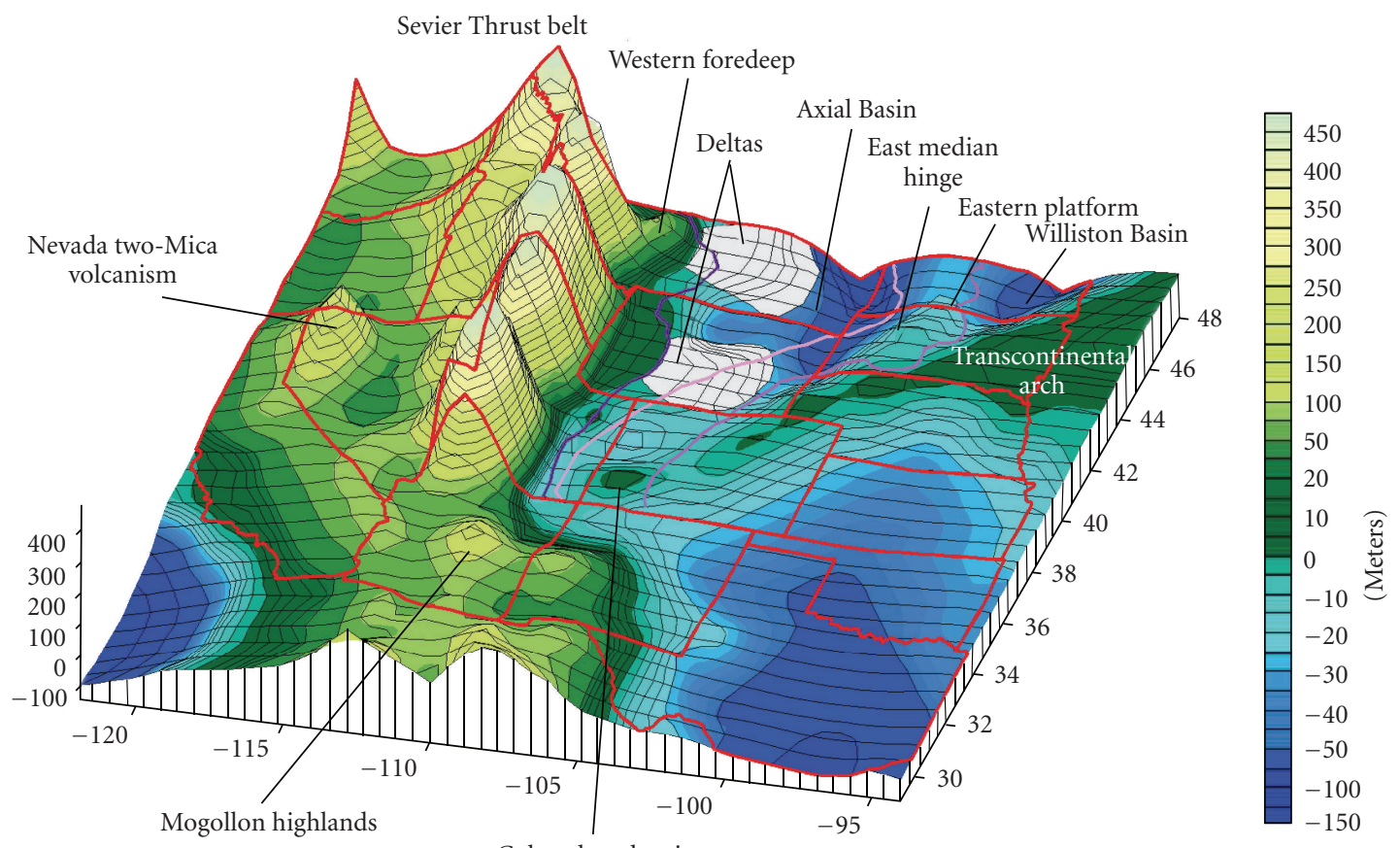

Colorado volcanism

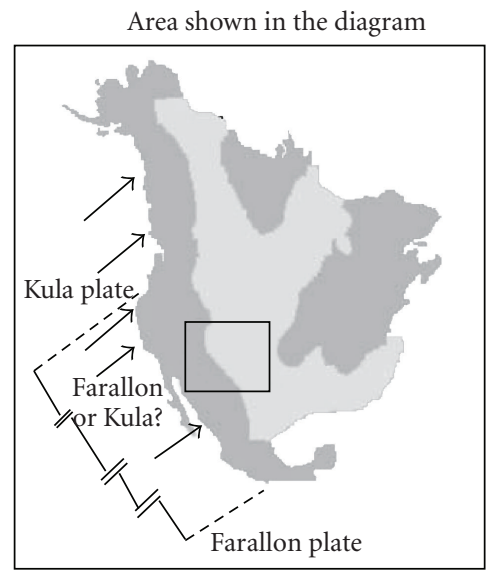

FIGURE 1: 3-dimensional reconstruction of the western interior seaway during the Baculites obtusus ammonite range zone. Colors indicate approximate elevations during this time. Blue is below sea level, green is above sea level. The darkest blue indicates the areas of deepest water. Red lines are modern state boundaries for reference.

The lower Pierre Shale Group represents distal sedimentation during multiple sea level fluctuations within an overall third order cycle, and resulted from both tectonic and eustatic controls. The lower Pierre Shale was deposited within the eastern part of the axial basin, across the east median hingeline and onto the eastern stable platform. Broad structural zones were created in response to the tectonic forces to the west [11] (Figure 1). Superimposed on these zones, structural weaknesses in the crust caused local faulting, complicating sedimentation patterns [12]. Within the eastern part of the basin, structural weaknesses allowed for movement along the eastern stable platform, particularly in North Dakota, where ancient weaknesses of the Williston Basin allowed for increased subsidence associated with thrusting stresses [8]. In the southern part of the basin, the broad structural zones are not as well defined. This is partly a result of lower tectonic activity in the southern part of the basin and partly due to the basin opening to the south into the open ocean. The northern and southern parts of the basin are at least partially isolated from each other by a structural high associated with the Transcontinental Arch. Sedimentation patterns indicate that the Transcontinental Arch was a prominent positive feature throughout the Late Cretaceous, and may have been subaerially exposed during periods of sea level lowstand. 


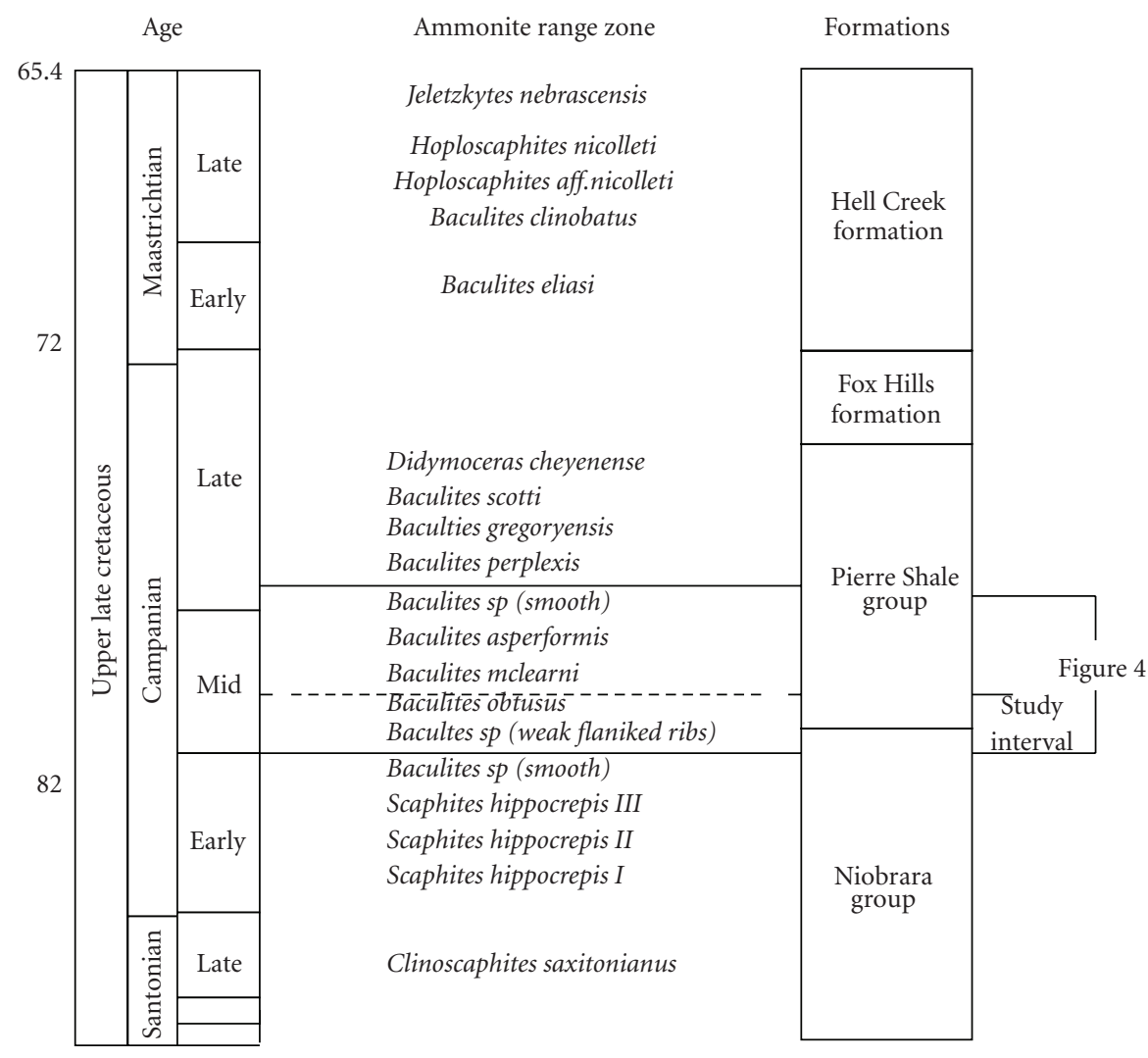

FIGURE 2: Generalized stratigraphy of the upper Late Cretaceous western interior of North America including European stage names corresponding with absolute age dates and North American ammonite range zones.

\section{Methods and Localities}

Detailed stratigraphic sections were measured and described for outcrops of the lower Pierre Shale in Kansas, Colorado, South Dakota, Wyoming and North Dakota. (Figure 5, Table 1). Published sections and subsurface information were used to supplement the field investigations for Kansas, Colorado, Nebraska, South Dakota, and North Dakota. Correlations were based on bentonite chemostratigraphy [10] and ammonite biostratigraphy where the information is available. Ammonites, however, are relatively rare in the organic-rich shales assigned to the lower Pierre Shale Group and are frequently confined to concretionary horizons.

Outcrops of the lower Pierre Shale were examined from eastern North Dakota to western Kansas at 12 outcrops (Figure 5). Only six representative sections are referenced in this paper. Full-measured sections for the additional outcrops can be found in Martin et al. [9] and Bertog et al. [10]. Additional information was obtained from published measured sections and subsurface data: eastern South Dakota localities [13], Nebraska subsurface [14], Redbird, Wyoming [13], northern Black Hills [15], southern Black Hills [16], Kansas [17, 18], eastern and central South Dakota [19, 20], and Colorado [21, 22].

\section{Background}

3.1. Tectonic and Eustatic Controls on the Deposition of the Lower Pierre Shale. Deposition of the lower Pierre Shale marks a time of numerous changes in the western interior seaway. During the middle Campanian, the Zuni II second order eustatic sea level cycle reached its peak during deposition of the Niobrara Formation when overall sea-level highs and tectonic quiescence favored carbonate deposition [11]. As this cycle began a regression that continued throughout the end of the Cretaceous, carbonate deposition gave way to clastic deposition, which dominated the seaway throughout the remainder of the Cretaceous.

Superimposed on an overall regression, third-order eustatic sea level fluctuations are recognized [11] (Figure 3). They are thought to be tectonoeustatic, resulting from increased sea floor spreading rates, which increased tectonism along seaway margins and increased subsidence rates within continental interiors while raising sea level due to displacement of water along the mid-ocean ridges [11]. Kauffman and Caldwell [11] have shown that these cycles roughly correlate to the eustatic sea-level changes proposed by Haq et al. [24] although they do not match perfectly. The Niobrara Cycle is represented by the Niobrara Formation and regression of this cycle is represented by the Gammon 


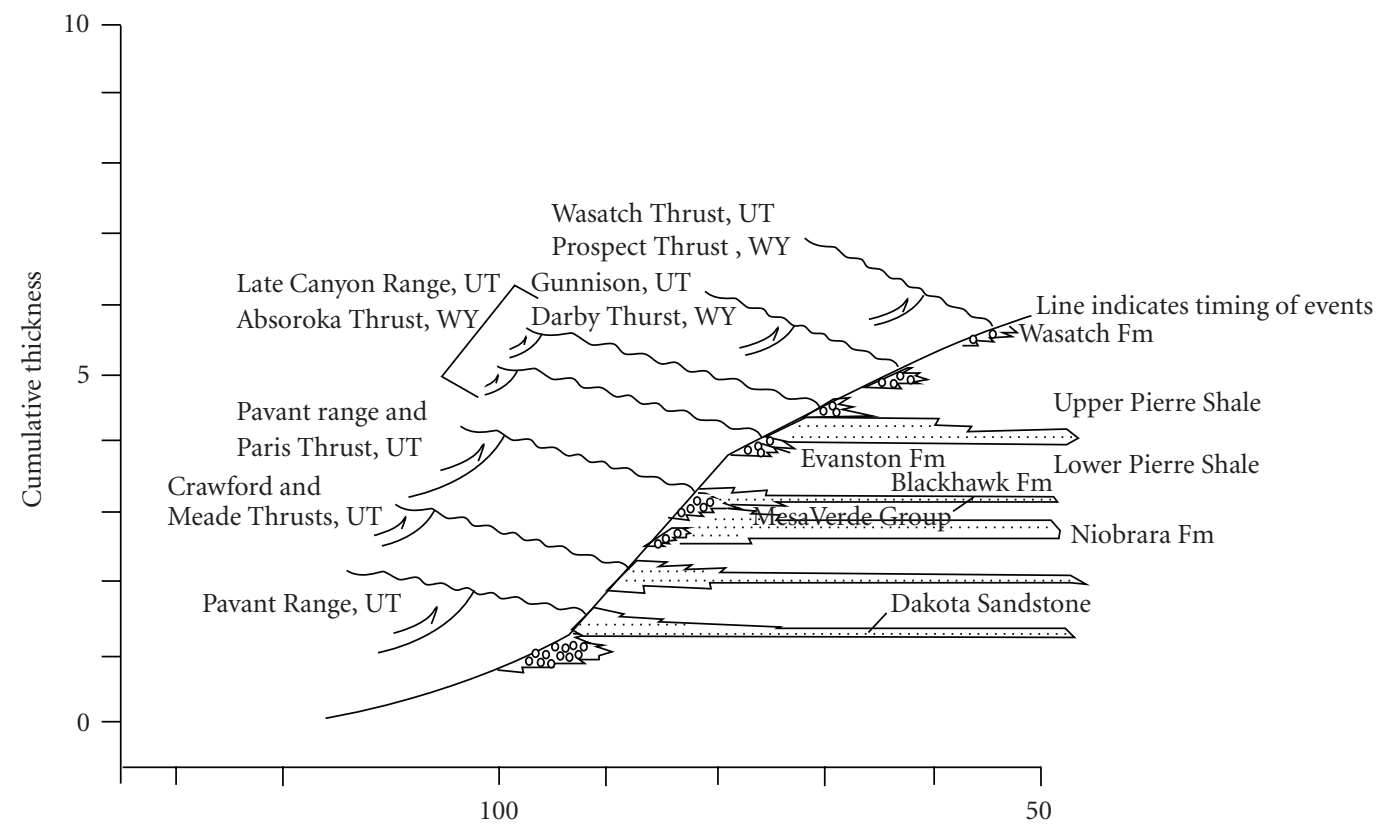

(Ma)

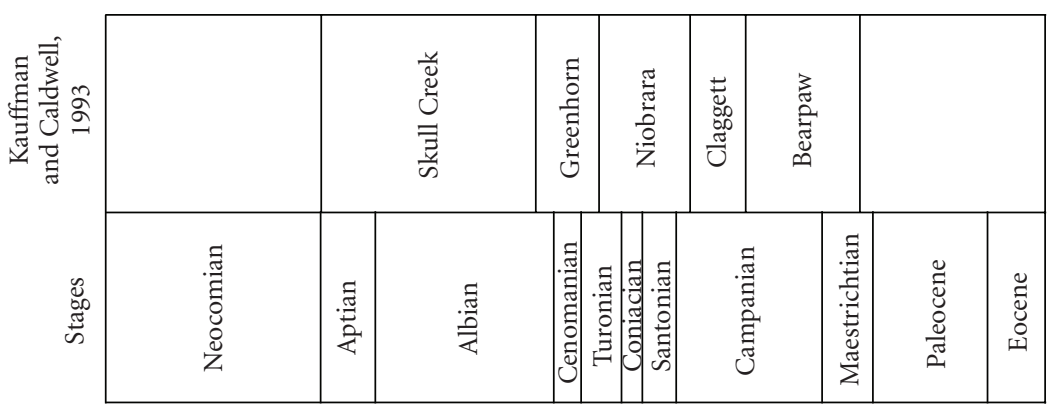

FIGURE 3: Thrusting events of Utah and Wyoming compared to stratigraphic units of the western margin of the western interior seaway. Orogenic thrusting events occur synchronously with transgressions in the basin [23]. The major cycles recognized by Kauffman and Caldwell [11] and generally accepted for the northern part of the seaway are shown, relating thrusting events to the transgression of these cycles. Some of the major stratigraphic units, particularly within the Campanian, are given for the western margin and the distal sediments. Tectonic material compiled from $[2,4,23]$.

\begin{tabular}{|c|}
\hline Ammonite zones \\
\hline Baculites scotti \\
\hline $\begin{array}{l}\text { Baculites } \\
\text { gregoryensis }\end{array}$ \\
\hline Baculites perplexus \\
\hline $\begin{array}{l}\text { Baculites sp. } \\
\text { (smooth form) }\end{array}$ \\
\hline $\begin{array}{l}\text { Baculites } \\
\text { asperformis }\end{array}$ \\
\hline Baculites mclearni \\
\hline Baculites obtusus \\
\hline $\begin{array}{c}\text { Baculites } \\
\text { sp (weakly ribbed) }\end{array}$ \\
\hline $\begin{array}{l}\text { Baculites sp } \\
\text { (smooth) }\end{array}$ \\
\hline
\end{tabular}

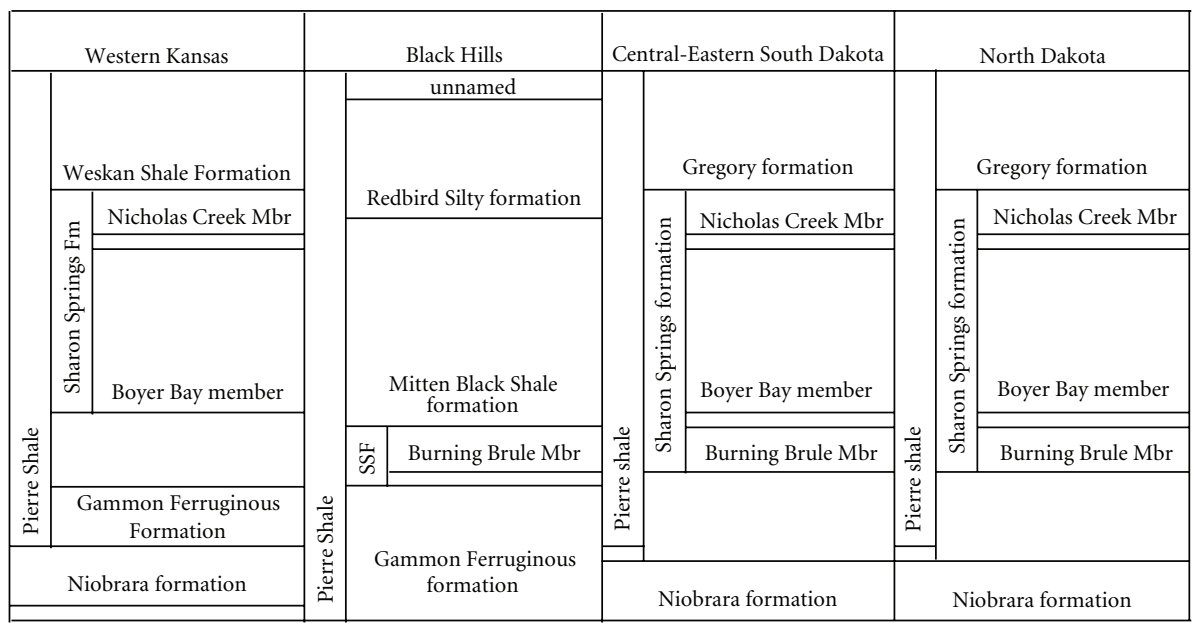

FIgURE 4: Stratigraphy of the lower Pierre Shale, as described in this paper. 


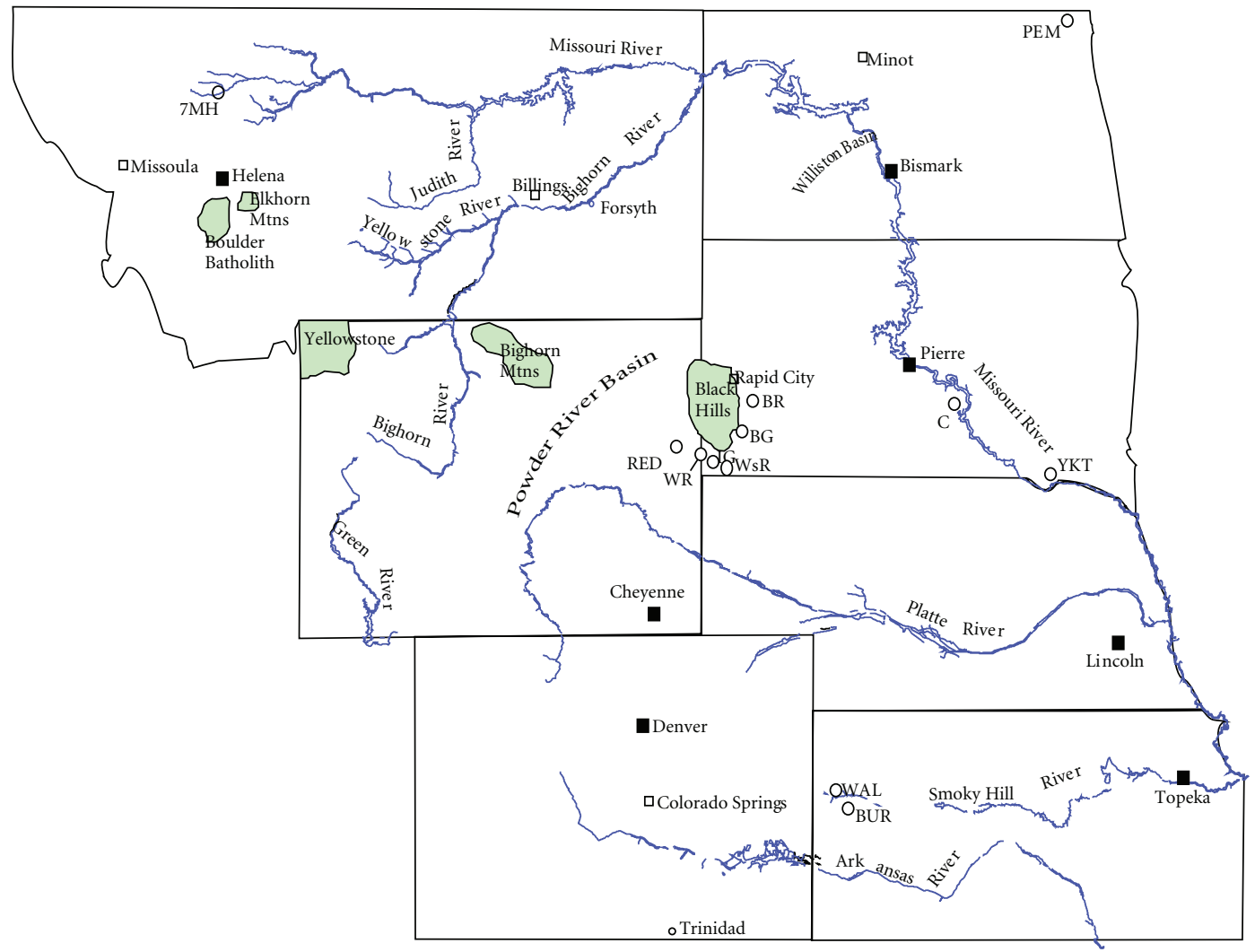

100 miles

FIGURE 5: Map of the Western Interior of North America showing major geographic features for the region. Open circles represent localities of the Ardmore succession that were included in this study. Locality abbreviations: WR (Wallace Ranch, South Dakota); IG (Igloo, South Dakota); WsR (Wasserburger Ranch, near Ardmore, South Dakota); BG (Buffalo Gap, South Dakota); BR (Brown Ranch, South Dakota); RED (Redbird, Wyoming); C (Chamberlain, South Dakota); YKT (Yankton, South Dakota); PEM (Walhalla, North Dakota); 7MH (Seven Mile Hill, south of Choteau, Montana); WAL (McAllaster Buttes, South Dakota); BUR (Burris Draw, South Dakota).

Ferruginous Formation in the Black Hills and western Kansas. During this eustatic sea level regression the eastern stable platform experienced a period of erosion, represented by an unconformity at the top of the Niobrara Formation. Sedimentation patterns follow an east to west dichotomy of deposition consistent with the facies belts described by Kauffman and Caldwell [11]. The organic-rich shale of the lower Pierre Shale has been considered the transgression of the third-order Claggett Cycle throughout the Western Interior Seaway [11].

Although the cycles of Kauffman have been widely accepted, some authors disagree with this interpretation, contending that the cycles were proposed based on incomplete data. Lillegraven and Ostrech [25] suggested that the transgression and regression associated with the Claggett Cycle was restricted to the northern part of the basin in Montana and Canada, whereas in the southern part of the seaway a smaller-scale transgression and highstand occurred within the San Juan Basin. They suggested that the northern and southern parts of the basin were separate and responded to different tectonic conditions [25]. Lillegraven and Ostrech [25] recorded an overall regression from the zone of Collinaceras choteauensis (Santonian) through Didymoceras nebrascensis (Maestrichtian), recorded by Kauffman and Caldwell [11] as the regression of the Zuni Megasequence. From there, the interpretations vary significantly. In the northern part of the basin, the sea-level fluctuations recorded by Lillegraven and Ostrech [25] match those of Kauffman and Caldwell [11]. The Eagle Sandstone represents a progradation of the seaway correlating to the end of the Niobrara Cycle. The Claggett transgression is recognized by sediments of the Sharon Springs Formation in the northern part of the basin. Cobban et al. [26] supported the notion that the transgression was restricted to the northern part of the basin. In the southern part of the basin, Lillegraven and Ostrech [25] recorded a number of localized transgressions and regressions, none of which can be correlated throughout the entire basin. Rather, they exhibited segregation between the northern and southern parts of the basin. Lillegraven and Ostrech [25] recorded a lengthy interval of transgressions, stillstands and regressions from the Baculites sp. (weak flanked ribs)_Baculites compressus zones. The initial transgression of this interval nearly coincides with the transgression of the Claggett Cycle at the 
Baculites obtusus range zone recognized by Kauffman [6], although it may have occurred slightly earlier in the San Juan Basin.

The various interpretations indicate that the seaway was much more complex than previously thought and casts doubt on the interpretations presented due to lack of continuity between any two sets of data. As would be expected in an active continental basin, eustatic sea-level fluctuations alone are not the only factor in the sedimentation patterns of the basin. The eustatic sea-level fluctuations are compounded by active tectonism along the western margin of the seaway. High-resolution interpretation of the seaway indicates that during periods of active tectonism in Utah and Wyoming, thrusting resulted in increased subsidence in the northern part of the basin, corresponding to the axial basin and the Williston Basin and resulting in a north to south dichotomy in sedimentation patterns. However, during periods of tectonic quiescence, sedimentation patterns reflected a retroarc foreland basin with north-south trending parallel facies belts. Based on stratigraphic interpretations, the base of the Claggett Cycle is placed at the base of the Boyer Bay Member of the Sharon Springs Formation (Figure 4) in central South Dakota, eastern Kansas and Wyoming and the base of the Mitten Black Shale Member in the Black Hills. The Burning Brule Member of the Sharon Springs Formation represents a tectonic cycle that predates the eustatic sea level change of the Claggett Cycle.

3.2. Structural Setting of the Western Interior Seaway. The broad tectonic setting of the Cretaceous Western Interior of North America was a retroarc foreland basin resulting from thrust loading during the Sevier Orogeny along the western coast of North America [27]. Precambrian and Paleozoic structural features that were reactivated by compressional forces from the west dissected this broad basin [28] (Figure 1).

During the Late Cretaceous, the western coast of North America was experiencing subduction of the Farallon Plate under the North American plate [29], resulting in the accretion of exotic terrains along the coast, the formation of a magmatic arc along the western margin of North America and thrusting of the Sevier Orogenic belt further to the east. Coincident with the deposition of the lower Pierre Shale, at about 80 million years, the Farallon and Kula plates were both moving north-northeast as they subducted under North America. Along the margin of the North America plate, orthogonal components were translated into contractional structures, while a northward component resulted in strike-slip motion [29].

In the northern part of the basin, tectonism was very active throughout the Campanian and deposition of the lower Pierre Shale was widely affected by these events. However, in the southern part of the basin, the seaway was broadly shaped by ancient tectonism and smaller-scale tectonism that was present in Arizona and Nevada during this time [30]. Six major thrusting episodes took place during the Late Cretaceous-Paleocene [23] (Figure 6). Thrusting along the Canyon Ridge Thrust in central Utah [31] and the Absoroka Thrust in Wyoming [2] is coincident with the

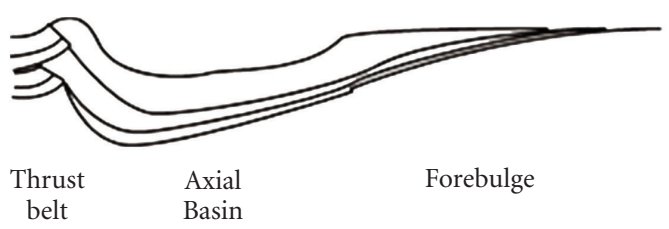

(a)

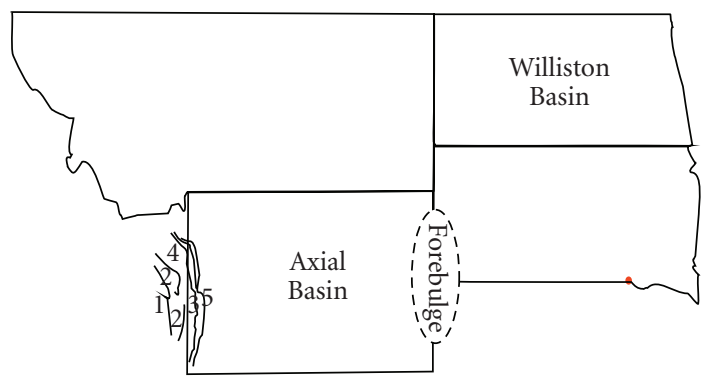

(b)

FIgURE 6: Thrusting activity in western Wyoming and Utah resulted in a broad foreland basin in the Western Interior. Cratonward of the foreland basin, a forebulge developed due to the stresses in the basin. (a) Cross-section of the Cretaceous Western Interior Seaway. (b) Map of the Cretaceous Western Interior Seaway in the northern United States showing the position of active faults in the IdahoWyoming thrust belt. 1 = Paris Fault, 2 = Meade-Crawford Fault, $3=$ Absoroka Fault, $4=$ Darby Fault, $5=$ Hogsback Fault.

initial deposition of the lower Pierre Shale [7]. The timing of these fault events and the deposition of the lower Pierre Shale have been considered coincident with the eustatic sea level rise $[11,24]$. The Absoroka fault was active from the Santonian to the Maastrichtian, with multiple discrete tectonic pulses [32]. This was the primary fault active during deposition of the lower Pierre Shale and resulted in the formation of the foreland basin to the east.

The western margin of the foreland basin was the deepest part of the basin structurally, due to subsidence resulting from high clastic sedimentation off the adjacent thrust belt. This zone, called the western foredeep, was $150-200 \mathrm{~km}$ wide and was the coastal plain of the Western Interior Seaway, represented by the Mesaverde Group and Two Medicine Formation [12]. To the east of the western foredeep, the compressional forces reactivated basement faults and created a western forebulge, resulting in structural highs that sequestered the coarse-clastics of the coastal plains within the western foredeep and separated them from the finer grained sediments to the east [11]. The finer grained sediments to the east were deposited in the axial basin or the west median trough, also called a back-bulge basin $[2,11]$. Due to lower sedimentation rates in this part of the basin, it was the bathymetrically deepest part of the basin. The deepest areas during this time interval were near the Wyoming-South Dakota border [12]. The axial basin is separated from the eastern platform by the east-median hinge, which is a peripheral bulge resulting from elastic bending of the crust [11]. This elastic deformation results from sediment load along the western margin, producing a 
basin adjacent to the sediment load and uplift on the distal margin of the basin [33] and was partially controlled by basement faults [12].

Basement faults in the basin weaken the crust and provide a region of slippage for the rebound, and so these basement faults were thought to have controlled the position of the peripheral bulge. The eastern platform, particularly in the northern part of the basin, was dissected by several lineaments and reverse faults trending dominantly northeast—-southwest with a minor northwest-southeast component that separated broad anticlinal blocks and narrow synclines and strike-slip features [34]. One of the most active faults during the Campanian was the Hartville Uplift in western Nebraska and southeastern Wyoming [31]. These lineaments signify initiation of Laramide-style deformation within the Western Interior Basin, where basement faults were reactivated and deep crust deformation segmented the basin [28]. These faults resulted in high areas along the Peace River Arch and Sweetgrass-Battleford Arch in Canada [35] and the transcontinental arch in South Dakota and Wyoming $[31,36,37]$ while the Williston Basin in North Dakota remained a low basin on the eastern platform [33].

3.3. Foreland Basin Models. Two basic models have been proposed for the deformation of continental crust in response to a thrust load. In the first model, the crust responds to the load through elastic deformation $[38,39]$ (Figure 7(a)). According to the elastic deformation model, lithospheric flexure occurs simultaneously with thrusting and the crust maintains its deformation until the stress is changed [39]. In viscoelastic deformation, the lithosphere weakens in response to increased thrust loading [40] (Figure 7(b)). The occurrence of synorogenic conglomerates proximal to the thrust belts, recording multiple transgressive-regressive cycles, appears to support the viscoelastic model [41]. However, odeling of the Late Cretaceous Western Interior is complicated by the initiation of Laramide-style basement faulting beginning in the Campanian [3, 29, 42]. As a result of this basement faulting, it is often difficult to discern whether a topographic high is a peripheral bulge responding to flexure of the basin or a response to basement faulting [3].

Flemings and Jordan [38] predicted changes in basin wavelength corresponding to basinal response on an elastic lithosphere. In their model, initial thrusting results in narrowing of the basin and migration of the forebulge towards the thrust belt. Continued thrusting and relaxation results in migration of the forebulge cratonward. According to their model, flexure responding to tectonic loading takes place on a scale of less than five million years. This is consistent with an elastic model in which the lithosphere is responding instantaneously to thrusting.

In contrast, Quinlan and Beaumont [40] proposed a viscoelastic model for the Appalachian foreland basin and the development of peripheral bulges such as the Cincinnati and Findlay Arches. In a viscoelastic model, initial response to a thrust load is identical to that of an elastic model, with the formation of a broad shallow foreland basin and a low forebulge. With a viscoelastic model, however, continued presence of the thrust load results in weakening of the

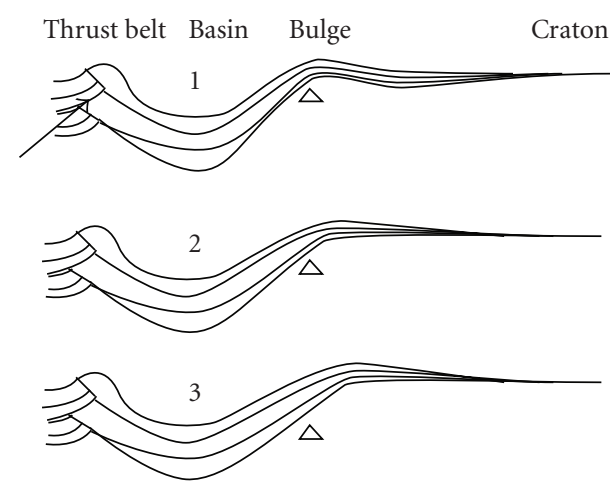

(a)

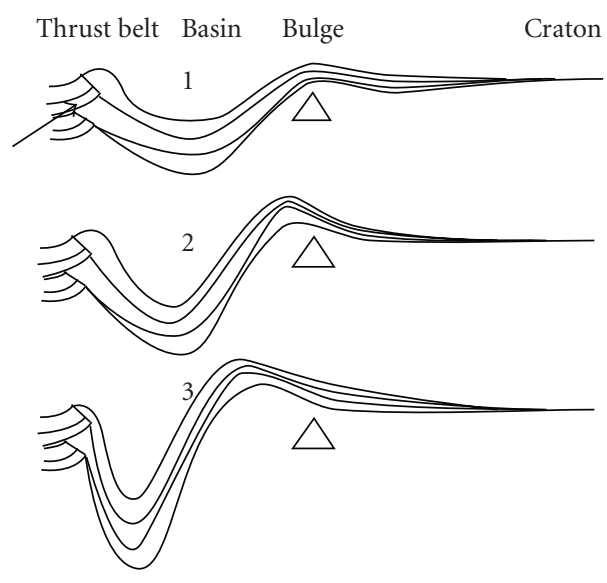

(b)

FIgURE 7: Comparison of the elastic and viscoelastic model of deformation. (a) In the elastic model, initial thrusting results in thrustward migration of the peripheral bulge (1). With continued thrusting and relaxation, the peripheral bulge migrates cratonward $(2,3)$. (b) In the viscoelastic model, initial thrusting results in cratonward migration of the peripheral bulge (1). With continued thrusting and relaxation, the peripheral bulge migrates thrustward $(2,3)$. The triangle represents a stable point to show migration of the bulge relative to this point. Models based on Appalachian basin structure [38-40].

lithosphere, resulting in flow of the lithosphere. With a viscoelastic model, continued presence of a thrust load results in deepening of the foreland basin and migration of the forebulge towards the thrust belt. Quinlan and Beaumont [40] also proposed a modified viscoelastic model, the temperature-dependent viscoelastic model. Under this model, the timing of the deformation and ultimate equilibrium is dependent on the temperature of the lithosphere, which ultimately controls the viscosity. The temperaturedependent viscoelastic model suggests that the lower part of the lithosphere flows on time scales of less than $1 \mathrm{Ma}$, while the upper part of the lithosphere is unable to flow on time scales within the age of the Earth. Because of the rigidity of the upper lithosphere, the crust in the viscoelastic model behaves identically to that of an elastic model. Therefore, the general consensus is that the shallow lithosphere behaves ultimately in an elastic fashion, responding directly to thrust 
loading and remaining deformed as long as the load is in place.

3.4. Intracratonic Basins. The Cretaceous Western Interior is similar to the Paleozoic Eastern Interior in that both regions experienced development of intracratonic basins in addition to the foreland basin [29, 40]. In the Cretaceous Western Interior, the Williston Basin in North Dakota was a prominent intracratonic basin during the Cretaceous [29]. Quinlan and Beaumont [40] describe the interaction of the Paleozoic foreland basin with the Michigan and Illinois intracratonic basins (Figure 8). Interaction between the basins depends in large part on the position of the two basins and the amount of space between them. In the case of widely spaced basins, no interaction will occur between the two. However, with basins that are more closely spaced, the two peripheral bulges will interact with each other, producing arching when the peripheral bulges overlap completely, or yoking of the basins when the peripheral bulges work to cancel each other. In the case of yoking, the two peripheral bulges coincide so that the overall amplitude of the two basins is lower than individual peripheral bulges, and the intracratonic basin becomes connected with the foreland basin.

The Williston Basin is a structurally controlled basin, resulting from weaknesses in the crust due to Paleozoic activity [29]. Therefore, the peripheral bulge associated with the Williston Basin was likely also in a fixed position. The foreland basin, on the other hand, was a dynamic basin and the peripheral bulge was free to migrate in response to stresses associated with thrust belt loading [40]. Therefore, the interaction of the foreland peripheral bulge with the Williston Basin peripheral bulge was a dynamic interaction resulting in a range from a decoupled basin to a yoked basin depending on the position of the foreland peripheral bulge.

\section{Results}

4.1. Stratigraphy of the Lower Pierre Shale. The Pierre Shale Group, one of the most widespread units in the western interior, was first described as a formation near Fort Pierre, South Dakota along the Missouri River for exposures of dark gray shale [43]. The formation was elevated to group status by Martin et al. [9]. The members have been elevated to formation status and will be described as formations herein, although they were originally described as members $[9,10]$. The Pierre Shale Group can be divided into two parts, particularly in the northern part of the basin [6]. The division between the upper and lower Pierre Shale Group is marked by the upper contact of the regressive facies of the Redbird Silty Formation and the equivalent but more distal Gregory Formation. The lower Pierre Shale Group is equivalent to the Claggett Shale and Judith River Formation in Montana [44].

4.2. Gammon Ferruginous Formation. The Gammon Ferruginous Formation was first described in the Black Hills region of South Dakota along the Gammon Prong in the northern Black Hills [45] and was extended across the Black Hills

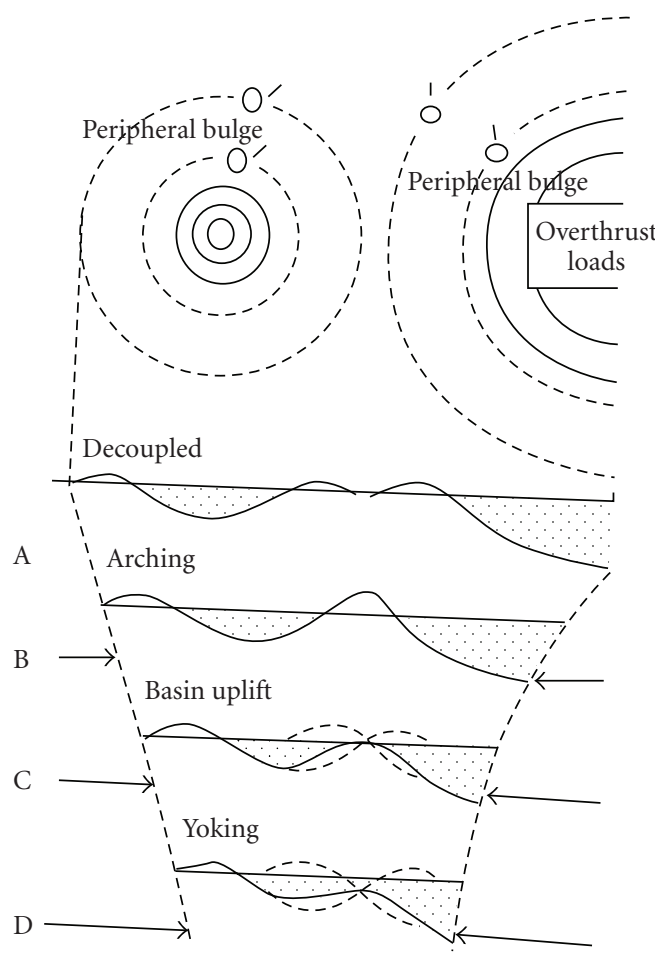

FIGURE 8: Interaction between the foreland basin and an intracratonic basin depends on the distance between the two basins. If the basins are widely spaced, the basins will be decoupled and no interaction will occur (A). With closer spacing, the peripheral bulge of the intercratonic basin and the foreland basin will overlap producing arch (B). With even closer spacing, the peripheral bulge of the foreland basin and the intracratonic basin will overlap creating a lowered peripheral bulge and resulting in yoking of the basins (C, D). Based on modeling from the Appalachian Basin by Quinlan and Beaumont [40].

region [13]. The Gammon Ferruginous Formation thins significantly from eastern South Dakota to western Wyoming over a distance of approximately 40 miles. At the type locality the formation is $300 \mathrm{~m}$ thick while at Redbird, Wyoming the member is $5.5 \mathrm{~m}$ thick and in the southern Black Hills at Slurp Flats, South Dakota, the formation is $10 \mathrm{~m}$ thick. Bentonites within this interval are present at both Redbird and Slurp Flats and indicate that the unit thins to the west due to condensation and not due to erosion and truncation $[10]$. This Formation is also recognized in western Kansas, where it had been previously referred to the "dark soft shale facies" of the Sharon Springs Formation [10, 18]. Although the characteristic ironstone concretions of the Black Hills are absent in Kansas, several layers of shale are iron-stained yellowish-orange and some scattered fossiliferous limestone and siderite concretions are present. Gill et al. [18] suggested that this was pre-Tertiary oxidation. The most complete section of the Gammon Ferruginous Formation in Kansas is along Burris Draw, where the unit is up to $30 \mathrm{~m}$ thick, southwest of Elkader in Wallace County, Kansas. Two meters of the facies are exposed at McAllaster Buttes, where it is unconformable with the overlying Burning Brule Member of the Sharon Springs Formation. The Gammon Ferruginous 
Formation is not present in eastern South Dakota and North Dakota, where a prominent unconformity at the top of the Niobrara Formation indicates a period of erosion during the time of deposition of this facies to the west. In the Black Hills and eastern Kansas the unconformity is at the top of the Gammon Ferruginous Formation. At Redbird, Wyoming, this unconformity is less evident, and two tabular siderite layers mark the top of the formation. At Igloo, South Dakota, the unconformity is well developed and overlain by a channel sandstone. The Gammon Ferruginous Formation is within the Baculites sp (weakly ribbed) ammonite range zone in Kansas $[10,13]$ and the Baculites sp (smooth) to Baculites sp (weakly ribbed) in the Black Hills region [13].

4.3. Sharon Springs Formation. The Sharon Springs Formation was originally described as the highly organicrich shale in western Kansas $[17,18]$. Similar facies were recognized in Colorado and in the Black Hills of South Dakota and Wyoming [17]. In the Black Hills, the formation was divided into three formations [13]. The member was correlated to central South Dakota [46, 47]. In North Dakota equivalent beds were described as the Pembina Member of the Vermillion River Formation [48]. Martin et al. [9] combined the Pembina Member with the Sharon Springs Member and elevated it to formation status, with three members- the Burning Brule, Boyer Bay and Nicholas Creek members (Figure 4). Because the Burning Brule Member is of interest in this study it will be described in more detail herein.

4.3.1. The Burning Brule Member. The Burning Brule Member of the Sharon Springs formation was defined near Chamberlain, South Dakota for exposures of bituminous shale [9] (Figure 9). The member is present in central South Dakota, the Black Hills (Figure 10), Nebraska and North Dakota. The member is not present in Kansas [10]. The member is highly variable in thickness, sometimes within a single outcrop, ranging from less than $1 \mathrm{~m}$ to $24 \mathrm{~m}$ thick (Figure 11). The variation in thickness is primarily due to several unconformities within the unit.

This member is the most organic rich facies of the lower Pierre Shale group. This shale is black, weathering to a dark brown, appearing "pulpy" and very hard, making it more resistant to weathering. Fragments of plants can be discerned in the shale and fish scales are very abundant. Weathered exposures of the bituminous shale do not support vegetation due to toxic materials such as selenite in the shale. The Burning Brule Member can be divided into two units, a lower unit that is hard and highly bituminous and includes the Ardmore bentonite succession $[10,16]$ and an upper unit of bituminous hackly shale with several thin bentonites [10]. The Burning Brule Member is bounded by unconformities (Figure 11). In addition, there are unconformities within the member, locally removing part or all of the two units. The member overlies the Gammon Ferruginous Member in the Black Hills and the Niobrara Formation in North Dakota and eastern South Dakota [10]. The member is within the Baculites obtusus to Baculites mclearni ammonite range zones.

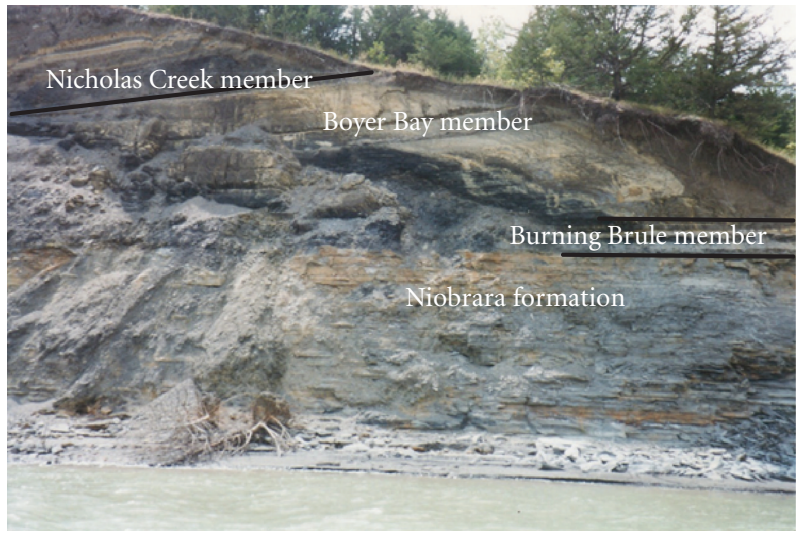

FIGURE 9: Stratigraphy of the lower Pierre Shale near Chamberlain, South Dakota. The Burning Brule Member is condensed at this locality. The Boyer Bay Member is approximately $5 \mathrm{~m}$ thick and the Nicholas Creek Member is also approximately $5 \mathrm{~m}$ thick.

Bentonite correlation has been used to correlate the members of the Sharon Springs Formation [10]. Through this correlation, the two units can be defined and unconformities can be recognized. The basal unconformity is clearly defined at most localities, and locally a sandy channel lag is present. The Gammon Ferruginous Formation thickens to the east across the Black Hills below this unconformity. At Redbird, Wyoming the formation is only $5 \mathrm{~m}$ thick. On the eastern side of the Black Hills the formation is $30 \mathrm{~m}$ thick.

Above the basal unconformity, deposition occurs earlier in the axial basin and the Williston Basin than on the eastern platform in eastern and central South Dakota, as indicated by the presence of five bentonite layers in the Black Hills and Williston Basin that are not present in eastern South Dakota.

Within the Ardmore succession, an unconformity marks the top of the first sequence. This unconformity is difficult to identify in the field at localities in the Black Hills, but it is well developed at eastern localities. In North Dakota, erosion associated with this unconformity removes four bentonites that are present in the Black Hills and eastern South Dakota.

At the top of the Burning Brule Member is another unconformity with considerable relief on it. At Redbird, Wyoming 12 bentonites are present below this unconformity. In the eastern Black Hills, the second sequence is half as thick as at Redbird, Wyoming and at least two bentonites are missing at the top of the sequence that are present at Redbird. At several localities in the south-central Black Hills, including Wallace Ranch, Igloo, Slurp Flats and Whiltey's Wash, the second sequence is considerably thinner. Only three bentonites at the top of the Ardmore succession are present at these localities. The remainder of the sequence is missing due to erosion associated with the overlying unconformity.

4.3.2. The Boyer Bay Member. The Boyer Bay Member of the Sharon Springs was defined near Chamberlain, South Dakota [9] (Figure 9). Unlike the Burning Brule Member, this member is present in central South Dakota, western Kansas 


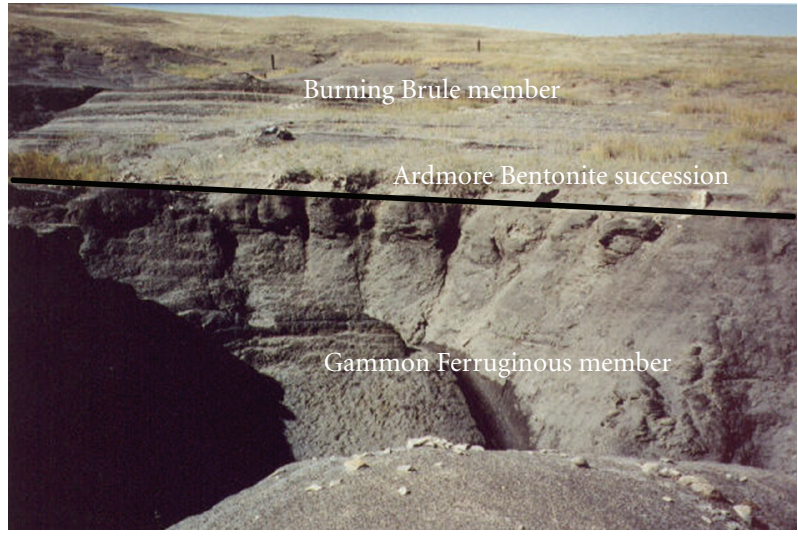

(a)

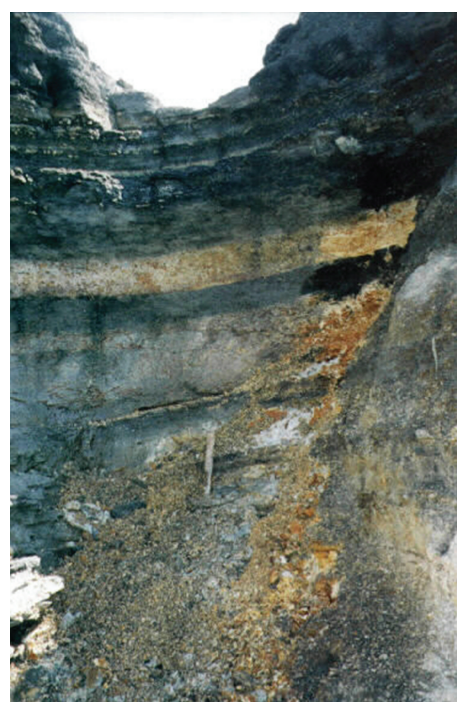

(b)

Figure 10: The Ardmore bentonite succession of the Burning Brule Member. Yellow bands on the outcrop are the bentonites. (a) The Ardmore bentonite succession at Wasserburger Ranch, the type locality of the Ardmore bentonite succession. (b) The Ardmore bentonite succession at Redbird, Wyoming.

(Figure 12) and eastern North Dakota, but not in the Black Hills (Figure 11). This shale is highly organic-rich siliceous shale with few thin bentonites. The member weathers to vertical slopes. The member is unconformable with the underlying Burning Brule and the overlying Nicholas Creek members [9]. The lower contact can have considerable relief on it while the upper contact is sharp. The member is within the Baculites mclearni ammonite range zone.

4.3.3. The Nicholas Creek Member. The Nicholas Creek Member of the Sharon Springs was defined near Chamberlain, South Dakota [9] (Figure 9) and like the Boyer Bay Member, is found in central South Dakota, western Kansas and eastern North Dakota, but not in the Black Hills (Figure 11). The unit is characterized by black, bentonitic shale with pinkish phosphatic concretions that may be scattered throughout the member or found in distinct layers.
TABLE 1: Locality abbreviations for sections that were studied. Full locality information can be obtained from the South Dakota School of Mines and Technology Museum of Geology.

\begin{tabular}{ll}
\hline \multicolumn{2}{c}{ Black Hills } \\
\hline WR & Wallace Ranch, Fall River County, South Dakota \\
IG & Igloo, Fall River County, South Dakota \\
WsR & Wasserburger Ranch, Fall River County, South Dakota \\
BG & Buffalo Gap, Fall River County, South Dakota \\
BR & Brown Ranch, Pennington County, South Dakota \\
RED & Redbird, Niobrara County, South Dakota \\
\hline & \multicolumn{1}{c}{ Eastern South Dakota } \\
\hline C & Chamberlain, Brule County, South Dakota \\
YKT & Yankton, Yankton County, South Dakota \\
\hline & \multicolumn{1}{c}{ North Dakota } \\
\hline PEM & Walhalla, Pembina County, North Dakota \\
\hline & \multicolumn{1}{c}{ Montana } \\
\hline 7MH & Seven Mile Hill, south of Choteau, Teton County, Montana \\
\hline & \\
\hline WAL & McAllaster Buttes, WallaceCounty, Kansas \\
BUR & Burris Draw, WallaceCounty, Kansas \\
\hline
\end{tabular}

The contact with the overlying Gregory Member in central South Dakota and North Dakota and the Weskan Black Shale Member in Kansas is sharp. The member is within the Baculites asperformis to Baculites perplexis ammonite range zones.

4.4. Mitten Black Shale Formation. The Mitten Black Shale Formation is temporally equivalent to the Boyer Bay and Nicholas Creek members of the Sharon Springs Formation but is restricted to the Black Hills of South Dakota and Wyoming, where increased detrital sedimentation occurred. The Mitten Black Shale Formation can be divided into four units at the most complete locality. Siderite concretions are common in the first unit, third unit and fourth unit. The second unit is devoid of concretions. In the northern Black Hills, only units 1 and 4 are present and clear unconformities marked by lags of phosphatized pebbles are present at the base of each unit. In the eastern Black Hills, only the fourth unit is present, and unconformably overlies the underlying Burning Brule Member of the Sharon Springs Formation. The Mitten Black Shale Formation is within the Baculites obtusus to Baculites perplexis ammonite range zones in the northern Black Hills and the Baculites asperformis to Baculites perplexis ammonite range zones in the southern Black Hills.

4.5. Other Formations of the Lower Pierre Shale. The Redbird Silty Formation is also restricted to the Black Hills [49] and is temporally equivalent to the calcareous Gregory Formation to the east. The Gregory Formation is a calcareous marl overlying the Nicholas Creek Member of the Sharon Springs Formation in eastern South Dakota and North Dakota [19]. In western Kansas the Weskan Black Shale Formation overlies the Sharon Springs Formation [17]. These formations are 


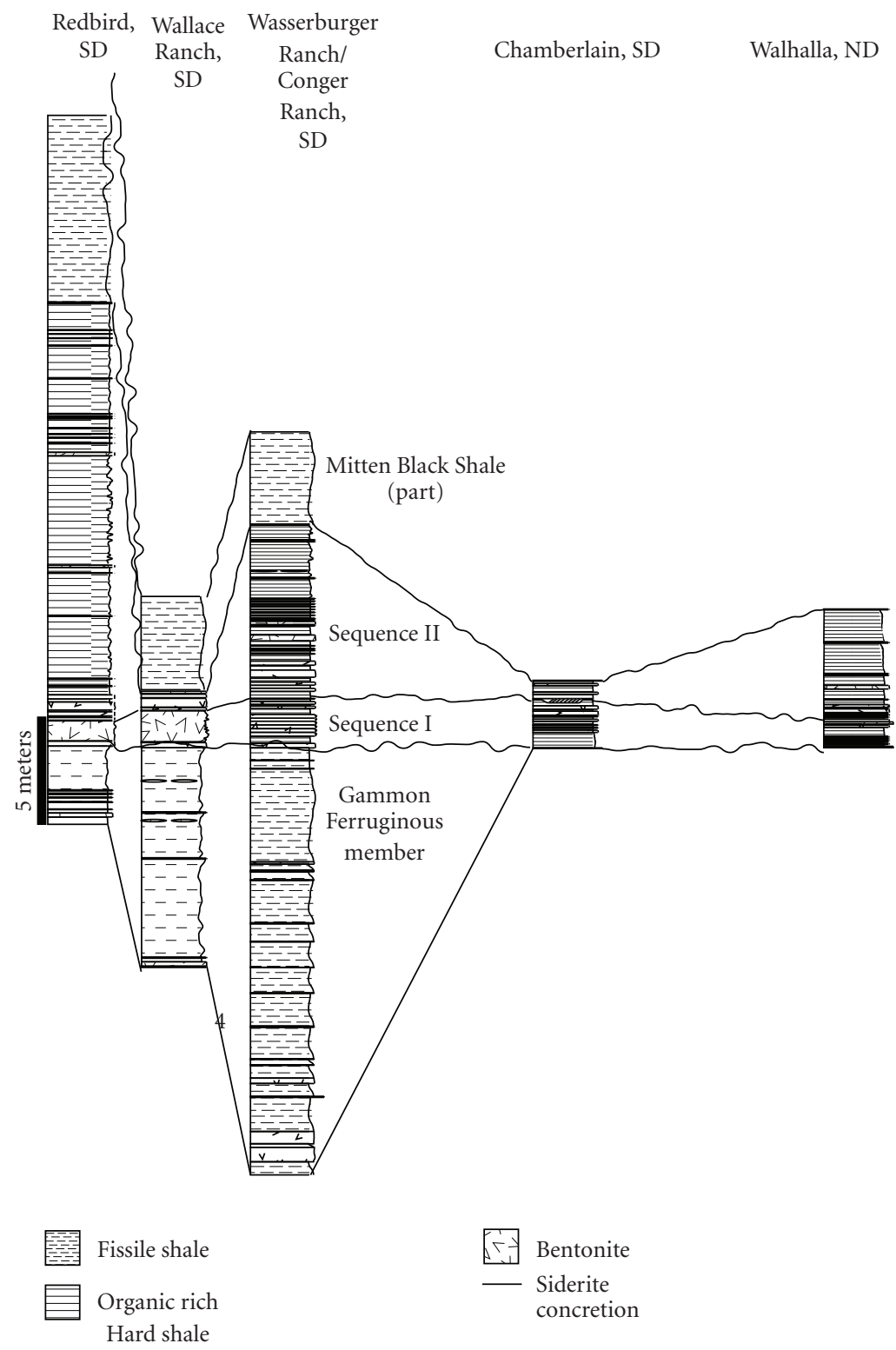

FIGURE 11: Stratigraphy of the lower Pierre Shale based on biostratigraphy and bentonite correlations. Sequence boundaries and thickness variations record a migrating peripheral bulge in the region around the Black Hills.

within the Baculites perplexis to Baculites scotti ammonite range zones.

\section{Discussion}

Eustatic cycles are represented in the sediments of the lower Pierre Shale by north-south trending facies belts, such as the Gammon Ferruginous Formation in the regressive phase of the Niobrara Formation. These belts are separated by their position in the foreland basin. During the highstand systems tract of the Niobrara Formation, the Gammon Ferruginous Member was deposited in the foreland basin while erosion was occurring on the eastern stable platform. However, between the Niobrara Cycle and the Claggett Cycle, a tectonic sequence is represented by the Burning Brule Member of the Pierre Shale. This member is restricted to the northern part of the basin, where tectonic activity was occurring, and resulted in subsidence of the axial basin in the Black Hills area and the Williston Basin in North Dakota (Figure 13). The eastern platform in central South Dakota was partially underwater but was shallow with frequent erosion taking place. Subsidence of the Williston Basin in conjunction with the axial basin was a result of structural weaknesses in the basement rocks of the Williston Basin, which allowed the basin to subside in response to the thrust forces. This subsidence was primarily restricted to these basins, and the eastern stable platform remained shallow and may have even bulged upward slightly resulting in shallowing of this region [5].

The thick bentonite of the Ardmore bentonite succession near the base of the Walhalla Member has been dated at 


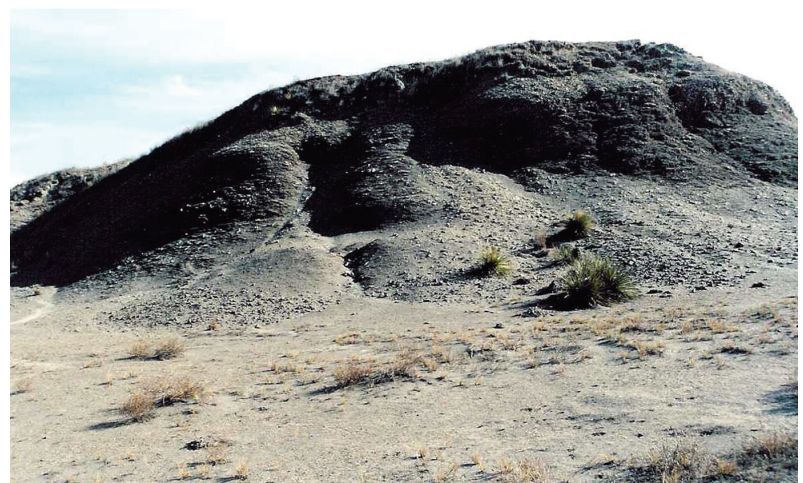

Figure 12: The Sharon Springs Formation at the type locality, McAllaster Buttes, Kansas. At the top of the outcrop is a layer of large septarian concretions.

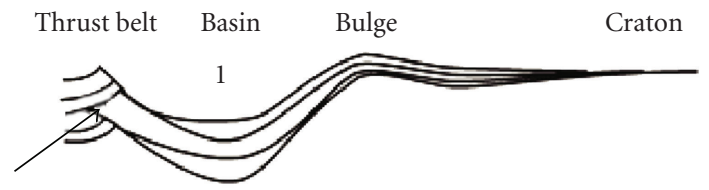

2
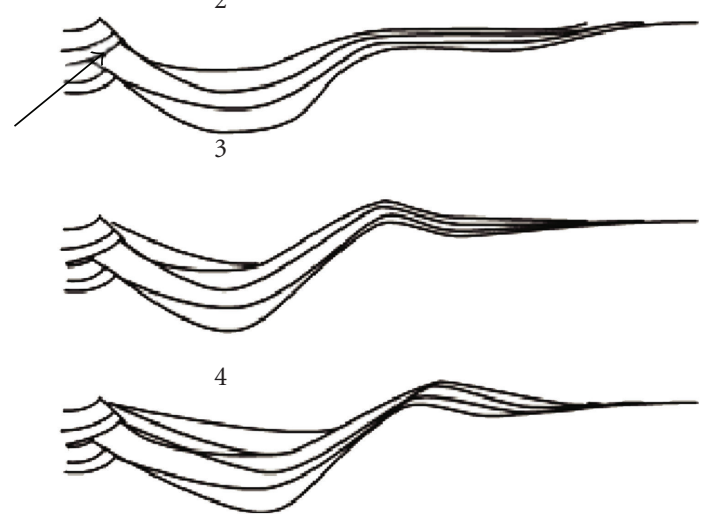

Figure 13: Model of the forebulge migration in the Black Hills region. (1) With initial thrusting, the forebulge migrates cratonward, producing a regional unconformity (the top of the Gammon Ferruginous Member, Figure 11). (2) Continued thrusting and cratonward migration of the forebulge results in overlap of the forebulge of the foreland basin and the peripheral bulge of the Williston Basin, causing yoking of the two basins. (3) Relaxation of thrusting results in deposition of coarse clastics in the basin, causing the basin to deepen and narrow, with thrustward migration of the forebulge. (4) Continued deposition of coarse clastics into the basin results in cratonward migration of the foreland basin and forebulge.

$80.5 \pm 0.55 \mathrm{Ma}[7,50,51]$. While this is within the range of potential error to coincide with the eustatic sea level change, it appears that the eustatic sea level rise, which is represented across the entire basin, actually occurred about $0.5 \mathrm{Ma}$ later than the sea level rise associated with the Burning Brule Member, during deposition of the Boyer Bay Member.

In Kansas, a lag bed at the unconformity that caps the Gammon Ferruginous Member contains phenocrysts from the bentonites of the Ardmore bentonite succession, indicating that deposition did occur in Kansas, and the sediments were subsequently eroded [10]. This area indicates that the area was shallow, compared to the eastern stable platform, throughout this time frame.

Two sequences are clearly preserved in the Burning Brule Member. In the first sequence, highly bituminous shale is interbedded with bentonites of the Ardmore bentonite succession. A locally well-developed transgressive lag marks the base of this sequence. Deposition of this sequence began earlier in the axial basin and the Williston Basin and during maximum flooding, progressed onto the eastern stable platform. In the axial basin, very low sedimentation rates resulted in deposition of multiple bentonites with no shale between them, resulting in a composite bentonite that correlates to multiple bentonites in the Williston Basin and the eastern platform [10]. An unconformity within the Ardmore bentonite succession marks the top of the first sequence. This unconformity has considerable relief on it, in some places removing all of the sediments between this unconformity and the base of the Burning Brule Member. This unconformity is best developed on the eastern stable platform. In the axial basin, no evidence of this unconformity is present.

Above this unconformity, and its correlative conformity in the axial basin, a second phase of transgression occurred. In the axial basin, this transgression is again indicated by sediment starvation and deposition of a composite bentonite that correlates to multiple bentonites to the east [10]. The top of the Ardmore bentonite succession was deposited during the transgressive phase of this sequence. The top of the Burning Brule Member represents the highstand systems tract of this sequence. Increased sedimentation during this period resulted in lower organic content in the shale, more hackly shale, and thinner bentonites. This unit was only deposited in the axial basin and the Williston Basin, indicating that the eastern platform became shallow and by the end of the second sequence, erosion occurred on the eastern platform. Following this second sequence, erosion extended across the entire basin and an unconformity with considerable relief locally removed all of the second sequence, even in the axial basin.

The two sequences appear to represent distal sedimentation during a single tectonic phase, as described by Ettensohn [5]. The first sequence records sedimentation resulting from rapid subsidence of the basin responding to deformational loading in the thrust belt that occurs in the subsurface. Because the deformation occurred in the subsurface, no clastic source was available, resulting in the accumulation of organic matter and sediment starvation in the axial basin. Preservation of organic matter was facilitated by a stratified water column typically associated with the initial transgression, resulting from circulatory restriction in a partly enclosed basin [5]. Low-oxygen conditions are indicated by abundant pyrite and selenite in the shale, as well as the abundance of planktic and nektic fauna (particularly vertebrate fauna) and the absence of benthic fauna. The axial basin was deepest during this initial phase, when tectonic forces were strongest. The regression of the first sequence resulted from relaxation of this structural load. 
This regression was relatively minor, and in the axial basin sedimentation was continuous while in the shallower eastern platform erosion occurs. The second sequence resulted from the formation of an antiperipheral bulge, which results in a second transgression. This transgression was not as extensive as the initial subsidence and transgression, but it does cover the eastern platform and allow sedimentation across the basin. Finally, relaxation resulting from unloading resulted in regression. Ettensohn [5] indicates that during this phase marginal marine sediments may extend across the basin and redbeds may be deposited, as displayed in the Appalachians. In this case, the second sequence of the Burning Brule Member was entirely marine, but does indicate increased clastic sedimentation and reduction of organic matter. This was followed by a second sequence boundary as the tectonic pulse ends and the seaway relaxes.

Within the Sharon Springs and Mitten Black Shale formations, the multiple unconformities indicate the presence and migration of a peripheral bulge responding to the stresses of the Absoroka Thrust belt (Figure 13). At the base of the Sharon Springs Formation is a regional unconformity that is present throughout the basin. This unconformity represents more time in the western Black Hills than in the eastern Black Hills, indicating that erosion occurred for a longer period of time to the west. This is consistent with the rapid migration of a peripheral bulge responding to initial thrusting [40]. As the thrust advances toward the basin, the basin and the associated foreland bulge migrate cratonward (as seen in [40]).

Following this regional erosion, deposition began earliest in the Black Hills region and in eastern North Dakota in the Williston Basin. This suggests that the peripheral bulge continued to migrate eastward, overlapping with the margin of the Williston Basin and resulting in yoking of the two basins. During this period, the resultant uplift had low amplitude and sedimentation occurred across the uplift.

As thrusting on the Absoroka Thrust ceased, the foreland basin subsided as a result of the deposition of coarse clastics to the west. Initially, this subsidence resulted in the peripheral bulge migrating westward, responding to subsidence of the foreland basin. Initial subsidence of the foreland basin and retrograde movement of the forebulge results in the initiation of the second sequence of the Burning Brule Member. This sequence is thicker in the western Black Hills than the eastern Black Hills, consistent with a transition from the axial basin in the west to the backbulge basin to the east. Clastic sedimentation continued to prograde into the foreland basin, distributing the stresses across the basin and resulting in cratonward migration of the forebulge during deposition of the Mitten Black Shale Formation.

\section{Conclusions}

Distribution of facies in the lower Pierre Shale indicates that north-south trending facies belts were present throughout deposition of most of the lower Pierre Shale. However, during deposition of the Burning Brule Member of the Sharon Springs Formation, facies patterns indicate that a north-south partitioning of the basin was present.
The Burning Brule Member in the northern Black Hills indicates the presence of a sequence created as a result of tectonic processes that were regionally restricted to the northern part of the basin and were a response to thrusting on the Absoroka Thrust in Wyoming. In the axial basin and the Williston Basin subsidence resulted, while the eastern platform in eastern South Dakota remained shallow.

Forebulge development in the Black Hills region during deposition of the Burning Brule Member is consistent with an elastic strain model for foreland basin development in response to thrust loading, coupled with the margin of an intracratonic basin. A temperature dependent viscoelastic model behaves identical to the elastic model in the shallow lithosphere and is an equally likely possibility [40]. Corresponding to the advance of the thrust belt, the foreland basin and the forebulge migrate cratonward, responding to increased stresses in the thrust belt. As the forebulge advanced cratonward, it overlapped with the margin of the intracratonic Williston Basin, resulting in yoking of the basins and deposition was continuous across the basins during early deposition of the Burning Brule Member. As thrusting halted, the foreland basin subsided responding to increased load from clastic sediments shed off the thrust belt. This resulted in deepening and narrowing of the foreland basin and thrust-ward migration of the peripheral bulge. Finally, with continued tectonic quiescence, clastic material was shed further eastward into the basin, distributing the load more uniformly across the foreland basin, resulting again in cratonward migration of the forebulge. Recognition of a forebulge in the Black Hills region corresponding to tectonic thrusting on the Absoroka Thrust provides for a more detailed analysis of the basin dynamics within this critical part of the basin.

\section{References}

[1] T. A. Cross and R. H. Pilger, "Tectonic controls of late Cretaceous sedimentation, western interior, USA," Nature, vol. 274, no. 5672, pp. 653-657, 1978.

[2] P. G. Decelles, "Late Cretaceous-Paleocene synorogenic sedimentation and kinematic history of the Sevier thrust belt, northeast Utah and southwest Wyoming," Geological Society of America Bulletin, vol. 106, no. 1, pp. 32-56, 1994.

[3] T. E. Jordan, "Thrust loads and foreland basin evolution, Cretaceous, Western United States," The American Association of Petroleum Geologists Bulletin, vol. 65, no. 12, pp. 2506-2520, 1981.

[4] D. V. Wiltschko and J. A. Dorr, "Timing and deformation in overthrust belt and foreland of Idaho, Wyoming and Utah," American Association of Petroleum Geologists Bulletin, vol. 67, no. 8, pp. 1304-1322, 1983.

[5] F. R. Ettensohn, "Compressional tectonic controls on epicontinetal black-shale deposition: Devonian-Mississippian examples from North America," in Shale and Mudstones I: Basin Studies, Sedimentology and Paleontology, J. Schieber, W. Zimmerle, and P. S. Sethi, Eds., pp. 109-128, E. Schweizerbart'sche Verlagsbuchhandlung, Stuttgart, Germany, 1998.

[6] E. G. Kauffman, "Paleobiogeography and evolutionary response dynamic in the Cretaceous Western Interior seaway of North America," in Jurassic-Cretaceous Biochronology and 
Paleogeography of North America, G. E. G. Westerman, Ed., pp. 273-306, Geological Association of Canada, 1984.

[7] J. D. Obradovich, "A cretaceous time scale," in Evolution of the Western Interior Basin, W. G. E. Caldwell and E. G. Kaufman, Eds., pp. 379-396, Geological Association of Canada, 1993.

[8] D. A. Russell, "Vertebrates in the Cretaceous Western Interior seaway," in Evolution of the Western Interior Basin, W. G. E. Caldwell and E. G. Kauffman, Eds., Geological Association of Canada Special Paper, pp. 665-680, 1993.

[9] J. E. Martin, J. L. Bertog, and D. C. Parris, "Revised lithostratigraphy of the lower Pierre Shale Group (Campanian) of central South Dakota, including newly designated members," in The Geology and Paleontology of the Late Cretaceous Marine Deposits of the Dakotas, J. E. Martin and D. C. Parris, Eds., vol. 427 of Geological Society of America Special Papers, pp. 9-22, 2007.

[10] J. L. Bertog, W. D. Huff, and J. E. Martin, "Geochemical and mineralogical recognition of the bentonites in the lower Pierre Shale Group and their use in regional stratigraphic correlation," in The Geology and Paleontology of the Late Cretaceous Marine Deposits of the Dakotas, J. E. Martin and D. C. Parris, Eds., vol. 427 of Geological Society of America Special Papers, pp. 23-50, 2007.

[11] E. G. Kauffman and W. G. E. Caldwell, "The Western Interior basin in space and time," in Evolution of the Western Interior Basin, W. G. E. Caldwell and E. G. Kauffman, Eds., pp. 1-30, Geological Association of Canada, St. John's, Canada, 1993.

[12] D. D. Rice and G. W. Shurr, "Patterns of sedimentation and paleogeography across the western interior seaway during time of deposition of Upper Cretaceous Eagle Sandstone and equivalent rocks, northern Great Plains," in Mesozoic Paleogeography of West-Central United States, M. W. Reynolds and E. D. Dolly, Eds., Rocky Mountain Section SEPM Paleogeography Symposium, pp. 337-358, 1983.

[13] J. R. Gill and W. A. Cobban, "The Redbird section of the Upper Cretaceous Pierre Shale in Wyoming," U. S. Geological Survey Professional Paper 393-A: A-1-A73, 1966.

[14] H. M. DeGraw, "The Pierre-Niobrara unconformity in western Nebraska," in The Cretaceous System in the Western Interior of North America, W. G. E. Caldwell, Ed., The Geological Association of Canada Special Paper, pp. 589-607, 1975.

[15] M. E. Wing, "Bentonites of the Belle Fourche district," South Dakota Geological Survey Report of Investigations 35, 1940.

[16] R. C. Spivey, "Bentonite in southwestern South Dakota," South Dakota Geological Survey Report of Investigations 56, 1940.

[17] M. K. Elias, “The geology of Wallace county Kansas," Kansas Geological Survey Bulletin, vol. 18, pp. 1-254, 1931.

[18] J. R. Gill, W. A. Cobban, and L. G. Schultz, "Stratigraphy and composition of the Sharon Springs Member of the Pierre Shale in Western Kansas," U. S. Geological Survey Professional Paper 728, 1972.

[19] J. P. Gries and E. P. Rothrock, "Manganese deposits of the Lower Missouri Valley in South Dakota," U. S. Geological Survey Report of Investigations 38, Vermillion, South Dakota, 1941.

[20] W. V. Searight, "Lithologic stratigraphy of the Pierre Formation of the Missouri Valley in South Dakota," South Dakota State Geological Survey, Report of Investigations 27, 1937.

[21] G. A. Izett, W. A. Cobban, and J. R. Gill, "The Pierre Shale near Kremmling, Colorado and its correlation to the east and the west," U. S. Geological Survey Professional Paper 684-A: A1-A19, 1971.
[22] E. R. Landis, "Radioactivity and uranium content, Sharon Springs Member of the Pierre Shale Kansas and Colorado," $U$. S. Geological Survey Bulletin, vol. 1046-L, pp. 299-318, 1959.

[23] A. Villien and R. M. Kligfield, "Thrusting and synorogenic sedimentation in central Utah," in Paleotectonics and Sedimentation in the Rocky Mountain Region, United States, J. A. Peterson, Ed., pp. 281-307, American Association of Petroleum Geologists Memoir, 1986.

[24] B. U. Haq, J. Hardenbol, and P. R. Vail, "Mesozoic and Cenozoic chronostratigraphy and cycles of sea-level change," in Sea-Level Changes: An Integrated Approach, C. K. Wilgus et al., Ed., pp. 71-108, SEPM Special Publication, 1988.

[25] J. A. Lillegraven and L. M. Ostresh Jr., "Late Cretaceous (earliest Campanian, Maastrichtian) evolution of western shorelines of the North American Western Interior seaway in relation to known mammalian faunas," Geological society of America Special Paper 243, 1990.

[26] W. A. Cobban, "Diversity and distribution of Late Cretaceous ammonites, Western Interior, United States," in Evolution of the Western Interior Basin, W. G. E. Caldwell and E. G. Kauffman, Eds., pp. 435-452, Geological Association of Canada, 1993.

[27] E. G. Kauffman, "Geologic and biologic overview: Western Interior Cretaceous Basin,” Mountain Geologist, vol. 14, pp. 75-99, 1977.

[28] G. W. Shurr and D. D. Rice, "Paleotectonic controls on deposition of the Niobrara Formation, Eagle Sandstone, and equivalent rocks (Upper Cretaceous), Montana and South Dakota," in Paleotectonics and Sedimentation in the Rocky Mountain Region, United States, J. A. Peterson, Ed., pp. 193212, American Association of Petroleum Geologists Memoir, 1986.

[29] J. W. H. Monger, "Cretaceous tectonics of the North American cordillera," in Evolution of the Western Interior Basin, W. G. E. Caldwell and E. G. Kauffman, Eds., pp. 31-48, Geological Association of Canada, St. John's, Canada, 1993.

[30] W. L. Bilodeau and F. A. Lindberg, "Early Cretaceous tectonics and sedimentation in southern Arizona, southwestern New Mexico, and northern Sonora, Mexico," in Mesozoic Paleogeography of West-Central United States. Rocky Mountain Section SEPM Paleogeography Symposium, M. W. Reynolds and E. D. Dolly, Eds., pp. 173-188, 1983.

[31] R. J. Weimer, "Relation of unconformities, tectonics, and sea-level changes, Cretaceous of Western Interior, USA," in Interregional Unconformities and Hydrocarbon Accumulation, J. S. Schlee, Ed., pp. 7-35, American Association of Petroleum Geologists Memoir, 1984.

[32] R. K. Schwartz and P. G. DeCelles, "Cordilleran foreland basin evolution in response to interactive Cretaceous thrusting and foreland partitioning, southwestern Montana," in Interaction of the Rocky Mountain Foreland and the Cordilleran Thrust Belt, C. J. Schmidt and W. J. Perry, Eds., pp. 489-513, Geological Society of America Memoir, Denver, Colo, USA, 1988.

[33] A. D. Miall, "Collision-related foreland basins," in Tectonic Controls and Signatures in Sedimentary Successions, L. E. Frostick and R. J. Steel, Eds., pp. 393-424, Blackwell, 1993.

[34] L. O. Anna, "Structural influences on Cretaceous sedimentation, northern Great Plains," in Paleotectonics and Sedimentation in the Rocky Mountain Region, United States, J. A. Peterson, Ed., pp. 173-193, American Association of Petroleum Geologists Memoir, 1986.

[35] C. R. Stelck, "Basement control of Cretaceous sand sequences in western Canada," in The Cretaceous System in the western 
interior of North America, W. G. E. Caldwell, Ed., The Geological Association of Canada Special Paper, pp. 427-440, 1975.

[36] G. W. Shurr, "Regional setting of Niobrara Formation in Northern Great Plains," American Association of Petroleum Geologists Bulletin, vol. 68, no. 5, pp. 598-609, 1984.

[37] G. W. Shurr, B. S. Larson, and I. W. Watkins, "Zuni sequence in Williston basin-evidence for Mesozoic paleotectonism," American Association of Petroleum Geologists Bulletin, vol. 73, no. 1, pp. 68-87, 1989.

[38] P. B. Flemings and T. E. Jordan, "Stratigraphic modeling of foreland basins: Interpreting thrust deformation and lithosphere rheology," Geology, vol. 18, pp. 430-434, 1990.

[39] T. E. Jordan, "Retroarc foreland and related basins," in Tectonics of Sedimentary Basins, C. J. Busby and R. V. Ingersoll, Eds., pp. 331-362, Blackwell Science, 1995.

[40] G. M. Quinlan and C. Beaumont, "Appalachian thrusting, lithospheric flexure, and the Paleozoic stratigraphy of the Eastern Interior of North America," Canadian Journal of Earth Sciences, vol. 21, no. 9, pp. 973-996, 1984.

[41] A. Schedl and D. V. Wiltschko, "Sedimentological effects of a moving terrain," Journal of Geology, vol. 92, pp. 273-287, 1982.

[42] D. V. Wiltschko and J. A. Dorr, "Timing and deformation in overthrust belt and foreland of Idaho, Wyoming and Utah," American Association of Petroleum Geologists Bulletin, vol. 67, no. 8, pp. 1304-1322, 1983.

[43] F. V. Hayden, "On the geology and natural history of the Upper Missouri," American Philosophical Society Transactions, vol. 12, no. 1, p. $218,1862$.

[44] T. S. Dyman et al., "Stratigraphic transects for Cretaceous rocks, Rocky Mountains and Great Plains regions," in Mesozoic Systems of the Rocky Mountain Region, USA, M. V. Caputo, J. A. Peterson, and K. J. Franczyk, Eds., pp. 365-392, Rocky Mountain Section SEPM, Denver, Colo, USA, 1994.

[45] W. W. Rubey, "Lithologic studies of fine-grained Upper Cretaceous sedimentary rocks of the Black Hills region," U. S. Geological Survey Professional Paper 165-A: 1-54, 1930.

[46] A. L. Moxon, O. E. Olson, and W. V. Searight, "Selenium in rocks, soils, and plants," South Dakota Agricultural Experiment Station Technical Bulletin, vol. 2, p. 94, 1939.

[47] A. L. Moxon, O. E. Olson, W. V. Searight, and K. M. Sandals, "The stratigraphic distribution of selenium in the Cretaceous Formation of South Dakota and the selenium content of some associated vegetation," American Journal of Botany, vol. 25, no. 10, pp. 794-809, 1938.

[48] S. R. Kirk, "Cretaceous stratigraphy of the Manitoba escarpment," Canadian Geological Survey Summary Report, vol. 1929B, pp. 112B-135B, 1930.

[49] J. R. Gill and W. A. Cobban, "Red Bird Silty member of the Pierre Shale, a new stratigraphic unit," U. S. Geological Survey Professional Paper 450-B: 21-24, 1962.

[50] J. F. Hicks, J. D. Obradovich, and L. Tauxe, "Magnetostratigraphy, isotopic age calibration and intercontinental correlation of the Red Bird section of the Pierre Shale, Niobrara County, Wyoming, USA," Cretaceous Research, vol. 20, no. 1, pp. 1-27, 1999.

[51] R. R. Rogers, C. C. Swisher, and J. R. Horner, "40Ar/39Ar age and correlation of the nonmarine two Medicine Formation (Upper Cretaceous), northwestern Montana, USA," Canadian Journal of Earth Sciences, vol. 30, no. 5, pp. 1066-1075, 1993. 

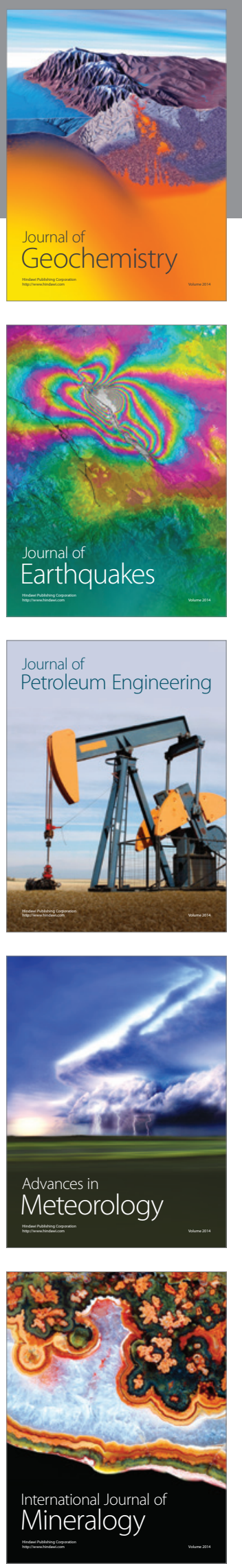
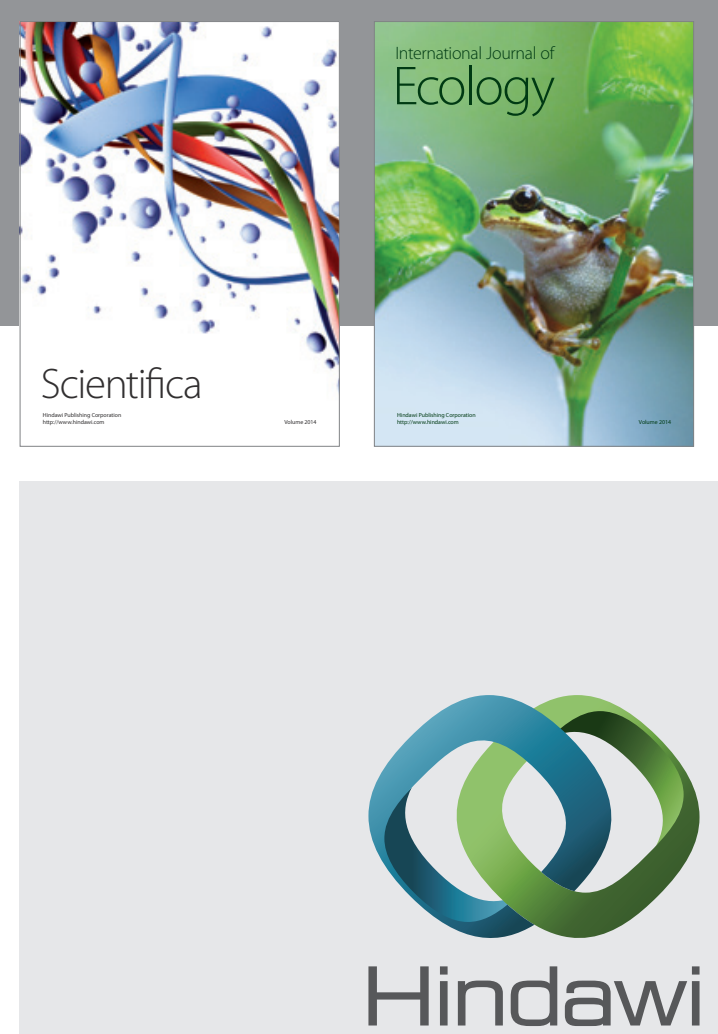

Submit your manuscripts at http://www.hindawi.com
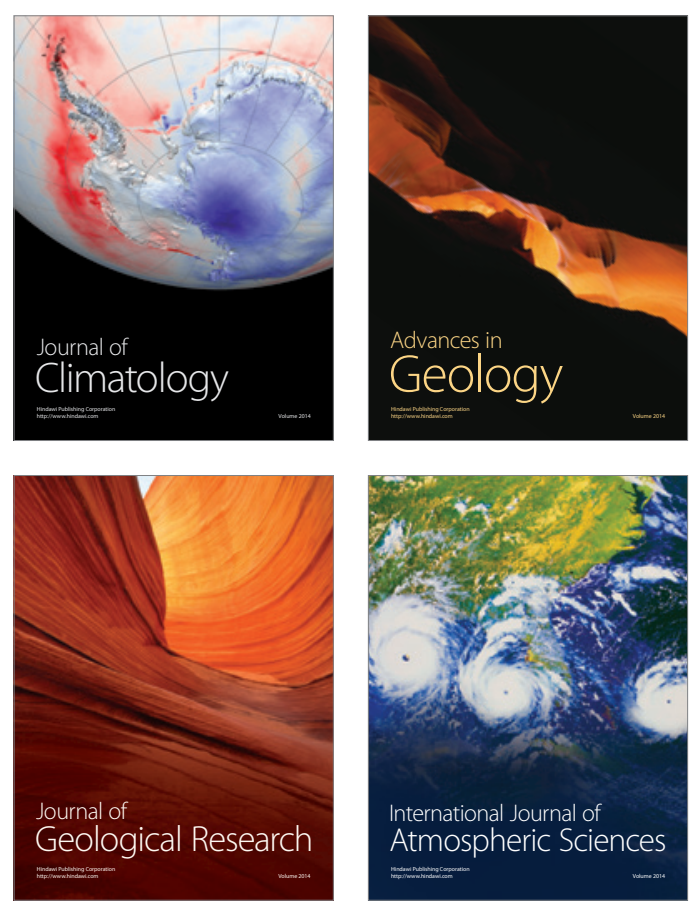
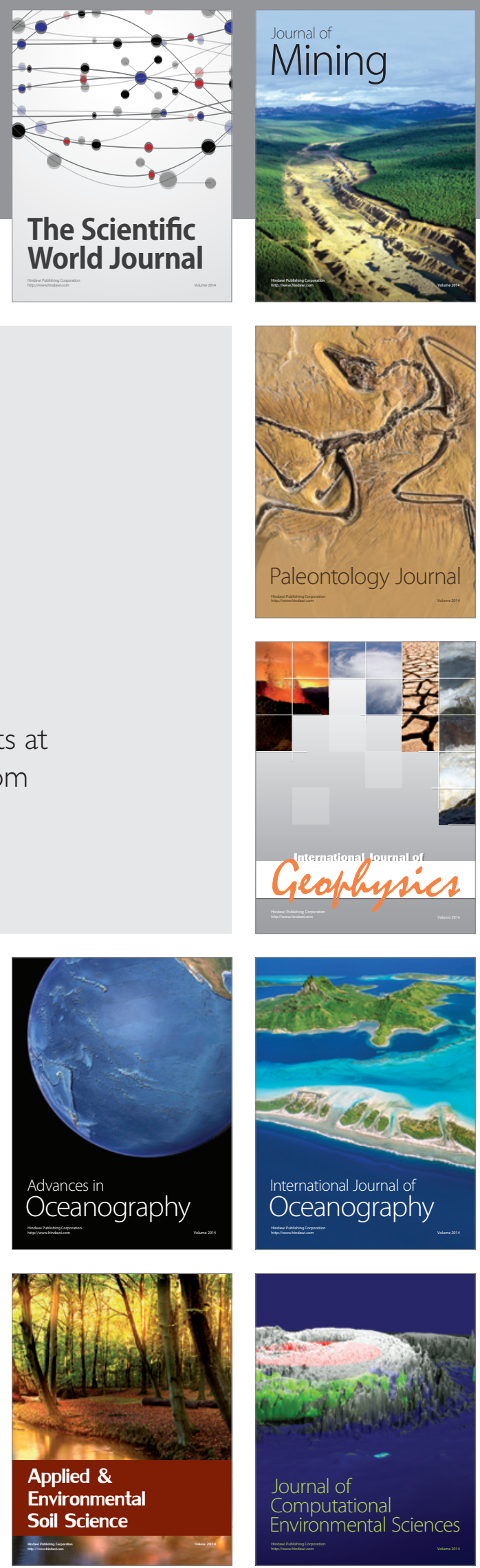